\title{
Adriaan Reland (1676-1718) and His Formative Years
}

\section{A Prelude to De Religione Mohammedica}

\author{
HenkJ. van Rinsum
}

[S] ometimes it takes a manifesto to get the world's attention. In 1705 Adriaan Reland (1676-1718), a professor of Oriental languages at the University of Utrecht, sent to the presses a compact octavo that would resonate across Europe out of all proportion to its modest size. ${ }^{1}$

ALEXANDER BEVILACQUA

Reland may not have been a follower of Descartes in every respectand indeed, how many Dutch Cartesians were?-but the influence of the new philosophy is evident in the novelty of his approach to the many subjects which he studied. ${ }^{2}$

ALASTAIR HAMILTON

Nostrum est integros accedere fontes. ${ }^{3}$

ADRIAAN RELAND

1 Bevilacqua, Republic of Arabic Letters, p. 83 .

2 Hamilton, 'Arabists and Cartesians at Utrecht', p. 105.

3 Reland, De consensu Mohammedanismi et Judaismi, p. 9. 
Writing about the work and influence of Adriaan Reland (1676-1718), it is tempting to place him in clear-cut intellectual-academic categories, neatly describing him and the dramatis personae surrounding him as Cartesians, humanists, Protestant theologians, Spinozists, and so on. In doing so we may avoid contradiction in a superficial sense; in reality, however, we obfuscate complexity. Similarly, it is fallacious to think about Reland and his time in linear developmental terms, speaking of major periods such as the 'Middle Ages', 'Renaissance,' 'Enlightenment', or 'Romanticism'. Intellectual developments are often paradoxical, contradictory, overlapping, and persistent. In people who live and work in times of major intellectual change, complexity is necessarily present. Reland, the subject of this chapter and this book, lived in one such period of great intellectual ferment.

Reland was born and raised in a Protestant family; his father was a minister in the Dutch Reformed Church. He never left his country, yet showed a deep interest in other countries, peoples, languages and religions, and was receptive to new methods of study. Although Reland wrote about many other subjects, attention is almost disproportionately focused on his De religione Mohammedica, which was first published in 1705. This 'manifesto' has a long preface in which Reland provides a justification for writing the book. As such, the preface offers a valuable insight into his ideas and is a good launchpad for our present investigation. 'Most religions that used to exist in this world or that are confessed today', Reland begins, 'have suffered the same fate: their opponents have not understood them properly, or they have been denounced with improper slander and in an unfair manner. ${ }^{5}$

One thing is paramount: 'truth, wherever it is, should be investigated. ${ }^{6}$ This is why, according to Reland, it is important to describe another religion such as Islam 'as it is taught in the houses of worship and in the schools of the Muslims'.7 Reland states that he feels sorry for students who are interested in studying the Islamic religion but are referred only to the Summa controversiarum of Hoornbeeck (1617-1666), the apologetic Confusio sectae Mahometanae of

4 This chapter could not have been written without the help of my colleague and friend, the classicist Gert M. Knepper. I thank Christian Lange and Bart Jaski for their valuable feedback on a draft of this chapter. I thank the reviewers for their helpful comments.

5 Reland, De religione Mohammedica, 1705, Praefatio, I, n.p.: 'Plerarumque religionum, quae in orbe terrarum olim viguerunt aut vigent hodieque, idem fatum fuit, ut ab adversariis suis non satis bene intellectae, aut calumniose contra fas \& aequum fuerint traductae'.

6 Ibid., Praefatio, IV, n.p.: 'Veritas ubicunque est indagari debet'.

7 Ibid., Praefatio, IV, ${ }^{* *} 3:$ ' [...] sed ita uti docetur in Templis \& Scholis Mohammedicis [...]'. 
Johannes Andreas Maurus (fl. 1487-1515), or the version of the Quran translated by Robertus Retenensis (Robert of Ketton) (fl. 1143), 'and to others who have vehemently fantasized about this subject', ${ }^{8}$ while they should rather learn Arabic in order to get to know Islam from within.

This chapter is about individuals, institutions, disciplines, and world views. It is also about (the study of) religion and religions. In this respect, the year 1676 may be regarded as a fault-line. The key actors in this story are Gisbertus Voetius (1589-1676), professor of theology, Hebrew, and other Oriental languages in the faculty of theology of the University of Utrecht from 1634 until his death in 1676; and Reland, professor of Oriental languages in the faculty of philosophy at the same university from 1701 until his untimely death in 1718. Voetius died on 1 November 1676 , after a long and industrious life devoted to defending the reformed theology. Reland was born in De Rijp, a small village in the northern part of the province of Holland, on 17 July, only a few months before.

What united Voetius and Reland was a deep interest in religion. However, although both were reformed Christians, they differed fundamentally about how the religious systems of others should be studied, the relationship between philosophy and theology, and the nature of science and scientific methodology. One may argue that the transition from Voetius to Reland can be described as one from Glaubenswissenschaft to Religionswissenschaft. ${ }^{9}$ In Glaubenswissenschaft ' $[. .$.$] it is necessary then [...] to try to bring back to one$ of these religions all of its rivals, which shall be held to be "false" thanks to the establishment of "marks" guaranteeing the "true" one [...]'. By contrast, in Religionswissenschaft,

religion begins to be perceived from the outside. It is classified in the category of customs, or else in that of historical contingencies. [...] Religion no longer signifies a religious order or the Church in the singular: as Georges Gusdorf has remarked [in his Dieu, la nature, l'homme au siecle des Lumieres, Paris: Payor, 1972], 'Hereafter religion can be spoken of in the plural'. The contents of belief are subject to analysis from an increasing distance in respect to the act of believing. Religion tends to become

8 Ibid., Praefatio, VII ****.: '[...] aliosque, qui in hoc argumento vehementer hallucinati sunt'. Reland described the Qur'ān version by Robert of Ketton as 'ambigua' (see Reland, De symbolo Mohammedico, p. 10).

9 Here I find myself in line with Spaans and Touber, 'Introduction Enlightened Religion', and Krop, 'From Religion in the Singular to Religions in the Plural', both in a recent publication: Spaans and Touber (eds), Enlightened Religion. 
a social object, and hence an object for study, in ceasing to be for the subjects that which allows them to think or to behave. ${ }^{10}$

The emergence of a comparative study of religions at universities is mostly situated in the second half of the nineteenth century, when chairs in religious studies were established at various universities. In A New Science: The Discovery of Religion in the Age of Reason, Guy Stroumsa develops a different perspective on the genesis of the study of religion. He traces the genesis of a comparative study of religious phenomena 'back to the age of reason, broadly defined (the long Enlightenment, from 1600 to 1800 )." ${ }^{11}$ It is significant that Reland features prominently in his book.

In this essay, I will analyse Reland's formative years in Amsterdam, Utrecht and Leiden, particularly the tense intellectual-theological atmosphere at the University of Utrecht, and the role played by Voetius. Following this I will examine some of Reland's earlier writings, and extract features which I will describe as building blocks of the young Reland's critical philosophy and methodology. I want to show that Reland himself experienced a separation between the old and the new, between the philosophy of scholasticism and the new philosophy of nature, but also the separation between the domain of theology and (modern) philosophy. This will help us to understand why, a few years later, Reland was able to write De religione Mohammedica, which attracted so much attention in Europe and continues to do so today.

\section{$2 \quad$ Reland at the Athenaeum Illustre in Amsterdam}

At the age of eleven Reland began to attend to the city-sponsored Athenaeum Illustre in Amsterdam which, in the second half of the nineteenth century, became the University of Amsterdam. ${ }^{12}$ Education was mainly centred on the artes liberales. ${ }^{13}$ It did not feature the classical division into the four faculties of theology, law, medicine and philosophy, with the first three as the higher faculties. At the Athenaeum Illustre, Reland followed two trajectories that continued to influence his work until the end of his life. The first was training in the classics under the supervision of Petrus Francius (1645-1704), a professor of

\footnotetext{
10 Certeau, The Writing of History, p. $15^{2}$.

11 Stroumsa, A New Science, p. viii.

12 See Van Miert, Humanism in an Age of Science.

13 These liberal arts are divided in the trivium, including logic, grammar and rhetoric, and the quadrivium, including arithmetic, music, geometry and astronomy.
} 
rhetoric in a classical-humanist vein. The second was a strong philological trajectory with —initially—a strong emphasis on the study of Hebrew, supervised by Willem Surenhuis (c. 1664-1729) and Everard van der Hooght (1642?-1716).

Petrus Francius became professor of Roman history at the Athenaeum Illustre in 1674. He also taught rhetoric and Greek, and published partial editions by his pupils mainly of Ovid and Horace. A contribution by Reland, then only thirteen, was published in 1689, and another one in 169o..$^{14}$

Willem Surenhuis (Surenhusius) was the son of a German-born minister. He studied at the University of Groningen, and later taught in Amsterdam. He was a scholar of Hebrew, known for his Latin translation of the Mishnah, the compilation of Jewish oral traditions, which was published from 1698 to 1703 . As Peter van Rooden has noted, Surenhuis was probably the 'most philosemitic Christian Hebraist of the seventeenth century. [...] In general, Surenhuis wanted to keep the study of rabbinical literature separate from the theological polemics against Judaism. ${ }^{15}$

Everard van der Hooght was a minister who also taught Hebrew at the Athenaeum Illustre as a private lecturer. He made his name by publishing an Athias-Leusden edition of the Biblia Hebraica. The first and second editions were published by Joseph Athias, the Jewish printer of the Portuguese synagogue in Amsterdam, together with Johannes Leusden (1624-1699), professor of Hebrew at the University of Utrecht, and later the teacher of Reland. This 1705 edition was widely regarded as the textus receptus in Europe. Reland was one of several authors who wrote a judicium about this 1705 edition of his former teacher and predecessor, Johannes Leusden. Reland may also have been in contact with some of the Jewish scholars living in Amsterdam, first through Van der Hooght and then through Leusden.

The young Reland must have developed a strong devotion to the classical authors of antiquity and to Oriental languages, particularly Hebrew and rabbinical literature. Van der Hooght called him 'the wonder of his age' because of his talent for learning Latin, citing Cicero when he was only thirteen, as well as Hebrew and 'Chaldeeuwsch' (Aramaic). ${ }^{16}$ His mind was moulded by the atmosphere of the artes liberales, the Renaissance studia humanitatis in a humanistic-philological tradition, and the world of Oriental languages. The next step in his education was the University of Utrecht.

14 Reland, 'Saeculum argenteum, aeneum, ferreum'; and Reland, 'Q Horatii Flaccii, Epodon Od. 6. Quo, quo, scelesti, ruitis? \&c., Lib. 4. Od. 14'. Apparently, one of his co-authors, Bartolomeus Bolk, joined Reland at the University of Utrecht. He wrote a poem in one of the Reland's early disputations, De fine mundi conditi.

15 Van Rooden, 'The Amsterdam Translation of the Mishnah', p. 265.

16 Van der Hooght, 'Voor-reeden', n.p. 
City magistrates took the initiative to establish the University of Utrecht in 1636. Its main purpose was to train lawyers for the administrative hub that Utrecht was at that time; doctors; but above all ministers for the reformed churches in the Netherlands. They were meant to be trained in a strictly reformed orthodoxy. As early as $1634,{ }^{17}$ Gisbertus Voetius was appointed professor of theology in the faculty of theology. It was about theology, and reformed theology only. Voetius became a towering figure at the university in Utrechtalso known as the Academia Voetiana - devoting his life to the development and protection of the reformed theology. This orthodox reformed theology was codified by the Synod of Dordt in 1618-1619.

Voetius's reformed theology determined his engagement with philosophy as an academic discipline. According to him, philosophy was the mere handmaiden ('ancilla') of theology. ${ }^{18}$ This philosophy was a rigorous Aristotelian neo-scholasticism with its traditional notion of substantial forms in a Christian mould, thanks to Thomas Aquinas, who synthesized the philosophy of Aristotle with Christian theology.

Voetius, therefore, proved to be a fierce opponent of René Descartes (15961650), who lived in Utrecht for some time. The University of Utrecht became a battleground for the intellectual and theological conflict between Voetius and Descartes known as La Querelle d'Utrecht (the Utrecht Quarrel). Van Ruler describes this 'conflict between Scholastic and Cartesian ideas of natural change' as 'a conflictbetween finalistic and non-finalistic theories of causation.' 19 Are natural processes determined by divine providence or by mathematical physics? By freeing philosophy from the tentacles of a Protestant theology, Descartes jeopardized the sole authority of the Scripture, the principle of sola scriptura, not only in the domain of faith but also in the domain of the knowledge of nature. It meant that ratio and fides were positioned in a new relationship with one another. Cartesianism meant a 'complete revision of theological method', thus 'reopening the debate on Orthodoxy'. ${ }^{20}$ Voetius concluded that Cartesianism would eventually lead to atheism. The Dutch Cartesians counteracted this charge by advocating a strict separation between philosophy and the

17 From 1634 until 1636 the university was an Illustre School.

18 See e.g. Goudriaan, Reformed Orthodoxy and Philosophy, pp. 29-36, and Verbeek, Descartes and the Dutch, p. 6.

19 Van Ruler, The Crisis of Causality, p. 6.

20 Verbeek, 'Descartes and the Problem of Atheism', p. 222. 
higher faculties, including theology, law, and medicine. Philosophy and theology now came to serve different and more or less exclusive purposes.

The faculty of philosophy at Utrecht served theology, teaching the languages necessary for the proper interpretation of the Bible. Philosophy was a preparation for this 'higher faculty', and was supposed to sustain the theological disciplines. Only later did the academic discipline of philosophy emancipate itself in a process of differentiation in the humanities, including philology, the study of languages, philosophy; and natural philosophy, which increasingly developed in the direction of the 'experimental' natural sciences.

Voetius, religio vera, and the Use of Oriental Languages

According to Voetius, theology was actually missiology. In his De Plantatione Ecclesiarum he developed a broad definition of missiology as the establishment and growth of the Reformation and its doctrine. This fundamentally shaped his ideas about other religions. The binary religio vera/religio falsa was deeply rooted in his theology and missiology. An important example of the religio falsa was Islam. In his polemical disputatio De Muhammedismo, Voetius defines Mohammedanism as the 'complete apostasy in the denial of the true God and covenant of the gospel'. ${ }^{21} \mathrm{He}$ divided his disputatio into two parts, one about the 'nature of this evil', and the other about the 'healing of this evil'. In his preface to the 1656 edition of the Confusio Sectae Mahometanae, Voetius often used adjectives with a distinctly negative connotation, including 'falsa', 'absurda', 'injusta,' 'inhonesta' and so on, in opposition to the 'veritas religionis Christianae.22

Voetius's perspective on Islam was theologically driven by the concept of refutation, and not a vision based on a comparative study of religion(s). He assessed and appreciated Islam solely on the basis of knowledge of the revelation to the Jewish people and of Jesus Christ. ${ }^{23}$ In this sense, Voetius was the ultimate custodian of a (reformed) Glaubenswissenschaft.

21 Voetius, Disputatio de Muhammedismo, p. 66o: 'apostasia completa in abnegatione veri Dei \& foederis Euangelici'.

22 Voetius, 'Praefatio', in Andreas, Confusio sectae Mahometanae.

23 See Van Asselt, 'De islam in de beoordeling van Johannes Coccejus en Gisbertus Voetius', p. 229 . 
Knowledge of Oriental languages at Utrecht was dominated by the reading, understanding and interpretation of the Old Testament, with Hebrew seen as the most important language. It was the mother of all languages, the holy language of the Old Testament. It was Johannes Leusden who established a widely acknowledged tradition in the study of Hebrew and Jewish scholarship, partly based on his contact with the Jewish community in Amsterdam where he had stayed for some time, establishing, in the words of Turner, 'regular contact across a hostile border' separating learned Jews from Calvinist philologists. ${ }^{24}$ There he was taught by two masters, one of them an Arab Jew who probably also taught him Arabic. Leusden also worked closely with the Jewish printer Athias, 'an example of the new kind of cultural and religious exchange that was possible in seventeenth-century Amsterdam. ${ }^{25}$

The study of Arabic was regarded as important for two reasons. First, Arabic provided greater insight into the Hebrew language. And second, it enabled theologians to develop greater knowledge of the rival religion of Islam. In this respect, Voetius was also well aware of the importance of knowledge of the Arabic language and the Qurān. In the Dedicatio at the beginning of the Historia Orientalis (1651) by the Swiss Orientalist Johann Heinrich Hottinger (1620-1667), Voetius is quoted ('scribit Gisb. Voetius, Theologus Ultrajectinus') emphasizing the need for an annotated edition of the Qur'ān with a Latin translation. ${ }^{26}$

After all, in order to be able to fight the religio falsa, one needed to be familiar with its writings and language. Voetius himself had already begun to learn Arabic during his stay in the vicarage in Heusden. He even travelled to Leiden to consult the Arabist Thomas Erpenius (1584-1624) about teaching materials and the pronunciation of Arabic. And when the University of Utrecht did not succeed, after several attempts, in securing the services of the Walloon minister and Orientalist Louis de Dieu (1590-1642), Voetius was asked to teach Hebrew and other Oriental languages as well as theology.

24 Turner, Philology, p. 42.

25 See Dunkelgrün, 'Like a Blind Man Judging Colors', p. 88.

26 Hottinger, Historia orientalis, Dedicatio, n.p.: 'Alkoranum enim Arabicè cum versione Latina, et notis textualibus typis publicari deberet [...]'. 


\section{Reland as a Young Student at Utrecht}

At the age of fourteen, Reland moved to the University of Utrecht. His father found him lodgings at the house of the reformed theologian Melchior Leydecker (1642-1721), a faithful follower of Voetius. The Utrecht historian (and city mayor) Caspar Burman (1696-1755) called him very learned and skilful in Oriental languages. ${ }^{27}$ Reland's father had taken him there to keep him on the right track, in 'lubrica ista aetate' (Dutch: in 'deeze glibberjeugt', or English: in 'this hazardous state of youth'). ${ }^{28}$ Although the quarrel between Voetius and Descartes had subsided, some of the theology and philosophy professors still worked in the Voetian tradition.

In his first four years at Utrecht, from 169 o to 1694 , Reland studied in the faculty of philosophy. In this period, the following professors were active in the faculty: Johannes Graevius (1632-1703), professor of politics, history and rhetoric from 1661 onwards. Graevius played a crucial role in the College der Sçavanten, a group of Cartesian soulmates in Utrecht. ${ }^{29}$ One of his colleagues was Gerard de Vries (1648-1705), professor of philosophy and theology from 1674 onwards. He was called the 'Malleus Cartesianorum' ('hammer of the Cartesians'), who had come from Leiden to Utrecht after being bullied by Cartesian sympathisers at Leiden. Johannes Luyts $\left(1655^{-1721)}\right.$ was a professor of physics and mathematics from 1677 onwards. And Johannes Leusden, professor of sacred languages, taught from 1650 on.

In a way, this faculty was a mixture of the study of philology and Oriental languages, more particularly Hebrew (Leusden), of anti-Cartesian philosophy (De Vries and Luyts), and of a more humanistic and Cartesian-minded study of rhetoric, politics, and history (Johannes Graevius).

As a student in the faculty of philosophy, the following exercises (either 'disputatio' or 'exercitatio') bear Reland's name. I also include the name of the professors who chaired the disputes: ${ }^{30}$

27 Burman, Trajectum eruditum, p. 176: 'fuit revera vir multae lectionis et orientalium linguarum peritissimus'.

28 Serrurier, Oratio funebris, p. 16.

29 On the 'Collegie der Sçavanten', see Gootjes, 'The Collegie der Sçavanten'. Gootjes argues that Graevius stressed the scholarly element of the College.

30 A point of discussion related to the disputationes concerns authorship. Either the professor himself was the author, and the student reacted with theses (annexa respondentis) in the disputation, or the student himself wrote the disputation. A number of the disputationes explicitly mention 'Adrianus Reeland Auctor'. Note that Reland's assignments (disputationes and exercitationes) were mostly labelled as philosophical or philological-theological. 
1. Vindiciarum disquisitionis De mente non ipsa cogitatione (On the mind, not being thinking itself). Chair Gerard de Vries, 25 April 1694;31

2. Exercitatio Philosophica De fine mundi conditi (On the purpose of the creation of the world). Chair Gerard de Vries, 2 May 1694 ('Adrianus Reeland, Auctor');

3. Exercitationis physico mathematice De umbra Pars Prior (On the Shadow). Chair Johannes Luyts, 11 May $1694 .^{32}$

On 25 September 1694, at the age of eighteen, Reland defended his disputatio philosophica Inauguralis De libertate philosophandi (Pro doctoratus in Philosophia Gradu, ${ }^{33}$ to be conferred by Gerard de Vries) before an audience at the University of Utrecht. ${ }^{34}$ More than four years later, on 18 February 1699, he received his doctorate. ${ }^{35}$

After his studies in philosophy, Reland continued his studies in theology. His professors were Petrus van Mastricht (1630-1706), Melchior Leydecker, Hermannus Witsius (1636-1708), Hermannus van Halen (1633-1701), and Paul Bauldry (1639-1706). Witsius, coming from the University of Franeker, was a moderate theologian, and Bauldry a Huguenot living in Utrecht. Van Halen and Bauldry were less prominent, working mainly in the field of church history. Van Mastricht and Leydecker still taught in the Voetian tradition. However, we must guard against a strictly monolithic perception of the intellectual-theological milieu in Utrecht at that time.

During his studies in Utrecht, Reland met the German student Heinrich Sike, from whom he learned Arabic, and they became close friends. Sike was also closely connected to the Cartesian professor Graevius. ${ }^{36}$

31 This disputatio was probably written by Gerard de Vries himself. This disputation included Annexa Respondentis, possibly written by Reland.

32 This disputatio was probably written by Johannes Luyts himself.

33 Contrary to the disputatio sub Praesidio, the disputatio inauguralis gave access to the doctorate degree.

34 In the Acta et decreta senatus, it is stated: 'Adrianus Reland, Ripa-Batavus, praemissis ordinariis examinibus, inauguralem in Philosophia habuit disputationem "de libertate philosophandi"; "placuit Senatui summos honores academicos ipsi concedere, conferendos per virum clariss. Gerardum de Vries, quandocunque ei visum fuerit illos a nobis petere."' See Kernkamp, Acta et decreta Senatus, vol. 2, p. 142.

35 Ibid., p. 162: 'Adrianus Relandus, die op 24 Sept. 1694 een disputatie had gehouden "de libertate philosophandi", is gepromoveerd tot Philos. Doctor et A.L.M'. De Haan suggests that the long intermission between the defence in 1694 and the formal receipt of the degree in 1699 might be related to the young age of Reland at the time of the public defence (he was just 18 years old). De Haan, Het wijsgerig onderwijs, p. 71.

36 See Hamilton, 'Arabists and Cartesians at Utrecht'. 
The following exercises in the faculty of theology bear Reland's name (the name of the chair of the dispute is also included):

1. Dissertationis historico-theologicae De sermone Dei in origine universi, Pars Tertia \& Ultima (On the speaking of God at the beginning of the Universe). Chair Melchior Leydecker, 27 May 1696. 'Adrianus Reeland, Resp.; ; 37

2. Exercitatio philologico-theologica De consensu Mohammedanismi et Judaismi (On the points of community between Mohammedanism and Judaism). Chair Melchior Leydecker, 29 May 1696. 'Adrianus Reeland auctor';

3. Exercitatio philologico-theologica De symbolo Mohammedico (non est Deus nisi Unus) adversus quod S.S. Trinitas defenditur (On the Muslim creed (there's only one God) against which the Holy Trinity is defended). Chair Herman Witsius, May 1696. 'Adrianus Reeland auctor'.

\section{$7 \quad$ Reland at the University of Leiden}

From 1697 until 1698, Reland continued his studies at the University of Leiden, where he followed lectures in theology with Friedrich Spanheim (1632-1701), professor of church history and a fierce opponent of Descartes; with Jacobus Trigland (1652-1705), professor of theology; and with Johannes à Marck (1656-1731), professor of theology and church history. Marck was known as the 'Marckse Voetiaan'.

Reland also took courses in experimental physics (Dutch: 'proefondervindelijke physica') with Wolferdus Senguerdius, and did so with great interest. Senguerdius (1646-1724), son of Arnoldus Senguerdius (1610-1668), a professor at Utrecht and later at the Amsterdam Gymnasium, was appointed professor of philosophy in 1674. He was expected to teach Aristotelian philosophy, but during his professorship his views developed in various other directions. 'Nonetheless', as Ruestow notes, 'his own natural philosophy proved to be a strange and incongruous blending of obstructive traditionalism, Cartesianism, atomism, and experimentalism. ${ }^{38}$ With his colleague Burchard de Volder (1643-1709), Senguerdius is regarded as the founder of the teaching of experimental physics at Leiden, and prepared the transition to the 'experimental

This disputatio was probably written by Melchior Leydecker himself. Reland is one of the respondents.

$3^{8}$ Ruestow, Physics at Seventeenth and Eighteenth-Century Leiden, p. 79. 
philosophy' of the eighteenth century. Experimental physics became a distinctive feature of instruction at Leiden.

In 1679 Senguerdius designed an air pump which he used in his teaching. When Reland took courses at Leiden it had become a popular demonstration device. Following Francis Bacon (1561-1626), for Senguerdius the academic programme of the philosophy of nature was the 'marriage' of ratio and experiment (Rationis atque experientiae connubium). ${ }^{39}$ 'In fact', as Anne van Helden notes, 'it [the air-pump] had become a symbol of the new experimental philosophy. Indeed no instrument tuned in better than the air-pump with the rise of Baconism that so greatly influenced the scientific world in the late seventeenth and early eighteenth century' ${ }^{40}$ Serrurier's obituary of Reland mentions the latter's enthusiasm for the 'experimentis physicis \& mechanicis faciendis' that Senguerdius used in his teaching. Serrurier articulates a forceful dividing line that Reland experienced between the old and obsolete doctrine and the new way of uncovering the secrets of nature. ${ }^{41}$

As a student at Leiden the following student assignments bear Reland's name:

1. Dissertatio historica De Philippi imperatoris patris, et filii, credito temere Christianismo (On the father and son Emperor Philippus who are blindly believed to be Christians). Chair Friedrich Spanheim, May $1698 .{ }^{42}$

2. Disputatio theologica De paradisi sede temerè apud Jordanem quaesita (On the place of paradise that was inconsiderately searched for near the Jordan). Chair Johannes à Marck, 5 July $1698 .{ }^{43}$

During his studies at Leiden, Reland wrote extensive notes in a book by Johann Heinrich Otth (1651-1719), Historia doctorum misnicorum, ... Additae sunt huic editioni notae ab harum literarum studioso [i.e. Reland], which was published in 1699. According to Joseph Serrurier, Reland's notes attracted the attention of Jacob Rhenferd (1654-1712), professor of Oriental languages and Hebrew at the University of Franeker, who believed Reland had shown that he took the Jewish people and the Rabbinic writings seriously. ${ }^{44}$ In the prolegomena to the Historia doctorum misnicorum, Reland writes about the peculiar relationship

39 This is the title of a book of Senguerdius, published in 1715. It aptly summarises his academic work.

See Van Helden, 'The Age of the Air-Pump', p. 171. See also Shapin and Schaffer, Leviathan and the Air-Pump.

41 See Serrurier, Oratio funebris, p. 20.

42 This disputatio was probably written by Friedrich Spanheim himself.

43 This disputatio was probably written by Johannes à Marck himself.

44 Ibid.: 'equiori animo esse in gentem Judaicam'. 
between Christianity and Judaism: 'For what is the Christian religion other than a reformed Judaism, whose true principles it confirms and preserves?'45

After concluding his studies, Reland briefly taught Hendrik Bentinck, the son of Hans Willem Bentinck, confidant of the Stadtholder William III (16501702). As a result he stayed frequently on the estate Sorghvliet in The Hague, where he was also part of a 'society of students of wisdom. ${ }^{46}$ In this period, Reland made extensive notes in a book by Tanneguy Le Fèvre $\left(1615^{-1672}\right)$, the distinguished professor of Greek at the Academy of Saumur. It was supposed to serve as teaching material for Hendrik Bentinck and other students. The book, entitled Les Vies des poètes grecs en abrégé, was published in 1665 and again in 1700 in Amsterdam, Avec des Remarques, made by Reland.

In 1662 Tanneguy Le Fèvre published an edition of Lucretius's De Rerum Natura. In the entry on Empedocles (c. 495 BC-c. 435 BC) Tanneguy also mentions Lucretius (d. c. 55 BC). In this respect Reland noted that some see not only Empedocles but also Lucretius as a philosopher rather than a poet. This led Reland to comment: 'But perhaps this testimony will not be worth much to some people, who argue that Lucretius himself does not deserve the title of Poet. As for me, I do not want to dispute a tribute that the greatest Geniuses of antiquity have seen fit to bestow upon him. A few years ago, I wrote an Ode on this person, which appears at the end of these Remarks.47

In 170o, Reland's Ode In Poësin Lucretianam-apparently first published already in 1695-was indeed included in this publication. In 1701, this Ode was again included in a Dutch translation of Lucretius which was seen by Thijssen-Schoute and Hamilton, among others, as a token of Reland's alleged Cartesian sympathies. ${ }^{48}$

45 Otth, Historia doctorum misnicorum, p. 4: 'Quid enim est Christiana Religio, nisi reformatus Judaismus, cujus vera principia confirmat, \& tuetur'.

46 Serrurier, Oratio funebris, p. 24: 'societate virorum, quos vero nomine sapientiae studiosos appelandos esse censebat'. I have not found further information about this scholarly society. It might have resembled the College der Sçavanten in Utrecht (see n. 29 above).

47 Le Fèvre, Les Vies des poètes grecs, Remarques pag. 69, n.p.: 'Mais peut-être ce temoignage ne vaudra pas beaucoup aupres des certaines gens, qui soutiennent que Lucrece même ne merite pas le titre de Poëte. Pour moy, je ne luy veux pas disputer une louange que les plus grands Genies de l'antiquité luy ont accordée. Il y a quelques années, que j'ay fait une Ode sur ce sujet, qui pourra paroitre à la fin de ces Remarques'.

48 Thijssen-Schoute, Nederlands cartesianisme, p. 432, and Hamilton, 'Arabists and Cartesians at Utrecht', p. 104. 
In 1699, Reland was appointed as professor in experimental physics at the University of Harderwijk. In 1700 he delivered his inaugural address entitled De incremento, quod Philosophia coepit hoc seculo (About the progress that philosophy made in this century). Through the mediation of William III, Reland was soon asked to move to Utrecht as professor of Oriental languages and successor to Johannes Leusden, who had died in 1699. Apparently Reland felt relieved because he disliked the aggressive polemics conducted by supporters and opponents at the universities around Descartes' new philosophy. $\mathrm{He}$ started his appointment in Utrecht with an inaugural address entitled Pro lingua Persica et cognatis litteris Orientalibus in which he emphasized the importance of Persian and related Oriental languages for a better understanding of Hebrew, and with it the Old Testament, but also the 'religio Mohammedica'.

His neo-Latin poem Galatea, Lusus poëticus, was published in the same year, but without his knowledge. This love poem fits in perfectly with the tradition of the studia humanitatis, as well as with Reland's education at the Amsterdam gymnasium. ${ }^{49}$

\section{Reland's Critical Philosophy and Methodology}

Based on an analysis of some of his early publications, I argue that the young Reland's intellectual work displays the following four features: (1) the absolute freedom of a philosopher; (2) a transition from the old (neo-)Aristotelian, scholastic philosophy to the new Baconian empirical-experimental methodology of science; (3) critical philology and intellectual curiosity as an ars critica; and (4) an epistemological separation between theology and philosophy, with a corresponding interest in religions. These features testify to a critical philology and philosophy as a prelude to his De religione Mohammedica - an example of a newly developing Religionswissenschaft.

\subsection{The Absolute Freedom of a Philosopher}

A common thread running through Reland's early work is his view that scholars should never simply rely on the authority of any author whether of classical Antiquity or of the recent past. Scholars should always search critically for the truth and re-examine all the sources cited by other authors.

Already in 1694 he began one of his first exercitationes by referring to Descartes as a scholar 'who admits in the Méthode that as soon as his age allowed him to emerge from the control of his teachers, he took the decision only to seek knowledge found either in himself or in the great book of the

See Dirk Sacré's discussion of this poem elsewhere in this volume. 
world, ${ }^{50}$ Reland does not shy away from noting that this precept also applies to rising scholars in his own time, including Descartes, even when your teacher is as esteemed as Socrates. These notions of intellectual freedom and the rejection of authority are central to De libertate philosophandi, but also prominent in many of Reland's other writings.

In a way, the core of De libertate philosophandi is the aphorism that Reland

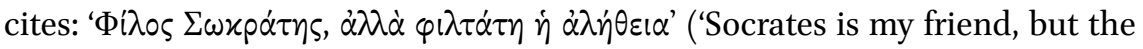
truth is an even better friend'). ${ }^{51}$ Reland constantly warned against adopting preconceived opinions and the indiscriminate imitation of existing writings or teachers without independent critical investigation. This, he believed, was why every philosopher should strive for intellectual independence. This perception of the need for critical research appeared in his early printed annotations of the works of Otth and Tanneguy.

In De libertate philosophandi, Reland presents himself as a philosopher who writes not so much about the content of philosophy as about the fundamentals of actually practising philosophy. And this young man made it abundantly clear that true philosophy means the distrust of any intellectual authority. Knowledge can only be based on one's own independent and critical research. Otherwise, philosophy is just another form of slavery to authority. The real virtue of the philosopher is that he accepts something, not on the basis of human testimony, but because it presents itself as true to him. ${ }^{52}$ 'The magnificent palace of philosophy would rest on a weak foundation if one only followed one's teachers.' ${ }^{53}$

Notably, Reland was not driven by methodic Cartesian doubt but by an awareness of the need for critical and independent research. This is also evident from his inaugural address in Harderwijk when he warns against preconceived opinions and forced authority. In his view, scholars should be guided only by reason. ${ }^{54}$ The inaugural addresses in Harderwijk and Utrecht may differ in content - the former dealt with the development of experimental

$50 \quad$ Reland, De fine mundi conditi, p. A.2: 'qui \& ipse in Methodo fatetur, se, ubi primum per aetatem licuit e praeceptorum custodia exire, consilium cepisse, nullam in posterum quaerendi scientiam, nisi quam, vel in se ipso, vel in vasto mundi volumine reperiret'. Reland, De libertate philosophandi, p. A 2. This aphorism, cited by Reland, was known in classical times although Plato sometimes features in the aphorism instead of Socrates.

52 Ibid., p. 5: 'Intelligimus itaque per Libertatem Philosophandi, illam Philosophi virtutem, qua ipse, nullius hominis impulsus testimonio, rei cuipiam, tantum quia ut vera offertur, praebet assensum'.

53 Ibid., p. 6: 'Infirma itaque basi praeclarum nitetur Philosophiae palatium, si solius Praeceptoris mens attendatur'.

54 Reland, De Incremento, p. 29: 'Libere philosophandum est, Auditores'; p. 37: '[...] praeconceptis opinionibus liberi, nullius auctoritate coërciti, nullis ducti partium studiis solaque Ratione [...]'. 
physics, and the latter with the importance of the study and knowledge of Persian and other related Oriental languages - but not in methodology, that is, the emphasis on independent critical research.

\subsection{A Division between the Old (Neo-)Aristotelian Scholastic Philosophy and the New Empirical-Experimental Methodology of Science}

Already in his De libertate philosophandi Reland was highly critical of the scholastic philosophy based on Aristotle's work:

So the Scholastics have made themselves very irrelevant to the Philosophical cause: fools, what do I say: idiots of Aristotle, who are attached to him, whom they are not ashamed to call the outer boundary of the human intellect. [...] people whom, if Aristotle had come back to life, he would have called natural slaves. ${ }^{55}$

Reland continued this line of argument in his inaugural lecture at the University of Harderwijk in which he reviewed the development of the new philosophy. He showed that he was well informed about the new natural philosophers, including Francis Bacon, Johannes Kepler (1571-1630), Galileo Galilei (15641642) and Descartes. He again praised the philosophers Petrus Ramus (15151572) and Pierre Gassendi (1592-1655) for uprooting Aristotelian philosophy, and noted that he is conscious of the fact that he is living in a time of a fundamental separation between the 'old' and the 'new', between an old-fashioned Aristotelian philosophy and the new perspectives of modern philosophy:

Nowadays [there are] no substantial forms, no qualities that make things work [...], [there is] no aversion to the vacuum or horror of nature, no suction or attraction, no forces that set in motion, [...]. True and more civilized Physicists ignore them [these notions], because they have learned better things through the experiments with the pneumatic pump. That is the machine that has taught us the hitherto unknown nature and condition of the air around us, and not only that, but of almost all bodies considered by the curiosity of the philosopher. ${ }^{56}$

55 Reland, De libertate philosophandi, p. 16: 'Pessime ergo meriti de re Philosophica Scholastici, moriones, miriones, inquam, Aristotelis eique quem limitem ingenii humani dicere non erubuerunt, adhaerentes'; p. 17: 'homines, quos, si revixisset Aristoteles, natura servos pronunciasset'.

56 Reland, De Incremento, p. 18: 'Nullas hodie Formas substantiales, nullas qualitates rerum effectrices [...] nullam vacui fugam aut Naturae horrorem, nullas suctiones attractionesve, nullas potentias motrices [...]'; p. 19: 'Negligunt illa germani \& politiores Physici, 
In many of his early writings, Reland presented Descartes as a rising star of his time, and writes about him in lyrical terms. However, at the same time-in line with his own emphasis on the absolute freedom of every philosopher-he also critically engaged with the philosophical writings of Descartes.

In the Harderwijk inaugural lecture, Reland praised the experiments and publications of two people in particular, namely Robert Boyle (1627-1691) and Francis Bacon. He had already written about Boyle in positive terms in his earlier disputations. Senguerdius's lectures on experimental physics in Leiden played an important role in this respect:

It is he [Francis Bacon] who was the first to make plausible, and exercise, the experimental philosophy, without which he quite rightly declared that the knowledge of nature was fruitless. He saw, and he also laughed, that great man, about philosophers who, philosophizing from the cells of their imagination as from Plato's cave, refrained from a proper investigation of natural things, and stubbornly stuck to prejudiced opinions, and everywhere followed and admired Aristotle as the only leader. The philosopher [Francis Bacon] did not endure this slavery of a mind that had been cleansed a little, but deliberately exhorted that philosophy should be restored from its foundations (a great work, indeed, that could not be done by one person) with experiments and daily attention to the things that fall under the senses. ${ }^{57}$

\subsection{Critical Philology and Intellectual Curiosity as an ars critica}

Reland's work up to and including his inaugural lecture in Utrecht in 1701 appears to be that of a critical philologist. He was keenly interested in language, text, and (cultural and historical) context, in how various peoples had spread throughout the world, and how their languages related to each other.

exhibitis per antliam Pneumaticam Experimentis meliora edocti. Haec illa machina est, quae ignotam hactenus aeris nos ambientis naturam \& dispositionem docuit, nec illam tantum, sed omnium fere corporum, quae curiositas Philosophi contemplatur'.

57 Ibid., pp. 10-11: 'Hic est, qui primus Philosophiam commendavit, \& excoluit ipse, Experimentalem, sine que sterilem esse cognitionem Naturae verissime pronunciavit. Videbat, \& ridebat quoque Vir Magnus, Philosophos ex phantasiae suae cellulis tanquam ex specu Platonis philosophantes a rerum naturalium indagatione justa abstinere, pertinaciter adhaerere praejudicatis opinionibus, unumque passim ducem sequi \& admirari Aristotelem. Non tulit hanc servitutem defaecatioris ingenii Philosophus sed instaurandam esse a fundamentis Philosophiam, (Magnum Opus, revera, nec ab uno perficiendum) Experimentalis \& attentione quotidiana ad res quae sub sensus cadunt, prudenter monuit'. Here, Reland explicitly refers to Bacon's grand scheme of the advancement of knowledge, the Instauratio Magna. 
He saw himself in line with famous predecessors, including Scaliger, Erpenius, Salmasius, Golius, Bochart, Pocock, Selden, Hottinger and many others and he wanted to revive this tradition of the studia humanitatis. Much to his regret, Reland concluded 'that the passion for this form of study seemed to have faded. It was not so much a neglect of, but a shameful aversion ('turpe fastidium') to, the letters of the East ('literarum Orientis')'.58

All of Reland's works display a high level of intellectual curiosity. However, he was also aware of the social scepticism about the tangible benefits of this studia humanitatis. After all, he writes with an undertone of irony, 'What is our connection with Arabs or Persians, people who live so far away from our world? [...] The peoples of Europe enjoy such a great light of literature that we expect in vain any increase in knowledge from those barbarians. ${ }^{59}$ Reland is clear about his mission: 'As you can all see, there is nothing more for me to do than to disprove those benefactors of ignorance and to prove that this study is very much worthwhile for you to dedicate yourselves to with all your heart'.60

The freedom of the philosopher and post-Aristotelian perspectives were important elements of his work, but its core was critical and contextual philology. For Reland, language and text were the pre-eminent sources if one did not wish to rely on established authority. He was also aware of the need to place language and text in the context of history and chronology, culture, religion, and the morality of groups of people. In his Harderwijk inaugural lecture, Reland spoke excitedly about the importance of the new experimental physics. One could argue that he brought a Boylean-Baconian empirical-experimental method to the domain of critical philology, and that he sought to use an inductive methodology based on collected information. However, Reland was happy with his quick shift to Utrecht where he could work more quietly in the field of the studia humanitatis, the field he loved most.

\subsection{An Epistemological Separation between Theology and Philosophy, with a Corresponding Interest in Religions}

Some writers point out that Reland was a reformed Christian first and foremost, and that his work on Islam (as well as his early Disputationes) should

$5^{8}$ Reland, Oratio Pro lingua Persica, pp. 6-7.

59 Ibid., p. 7: 'Quid nobis cum Arabibus aut Persis, populis ab orbe nostro remotissimis? [...] Gentes Europaeae tanta fruuntur literarum luce, ut frustra à Barbaris istis aliquod eruditionis augmentum expectemus'.

6o Ibid., p. 8: 'Nihil ergo mihi prius cogitandum \& agendum esse videtis omnes, quam ut istos ignorantiae fautores refellam, \& dignissimum esse hoc studium probem, in quod toto pectore incumbatis'. 
be evaluated in this perspective as well. ${ }^{61}$ However, I believe the relationship between his personal beliefs and his academic work was more complicated.

Reland begins or ends many of his writings with a devout prayer to God. He shows himself to be a religious and devout person who thanks his Lord for the academic work he can do. However, in sharp contrast with Voetius but in line with Descartes, he draws a fundamental and even epistemological distinction between faith and science. In line with his emphasis on the freedom of philosophizing and never accepting intellectual authority without proper critical enquiry, he also holds strong views on how philosophy relates to theology, or rather, on how both fields are separate and even exclusive 'categories' of knowledge that cannot be conflated.

Already in his De fine mundi conditi (1694), Reland essentially distinguishes between two sources of knowledge that should be independent of each other. He wants to separate 'Theologia' from (Cartesian) ratio. ${ }^{62}$

In his De libertate philosophandi, young Reland is very explicit about this separation. He speaks about different categories, different modes of knowledge production. Philosophy is distinguished from theology because one is based on science ('scientia'), the other on faith ('fides'). These are as different from each other as the freedom to philosophise is from slavery. Science investigates through reason, faith assures through a testimony. In theology God's voice commands us to believe, in philosophy recta ratio commands us to know ('In Theologia Dei vox credere; in Philosophia recta ratio scire jubet'). One is based on the light of grace, the other on the light of nature ('Illa Lumine gratiae, haec naturae nititur'). But when a philosopher beliefs a testimony of someone ('credere') and the theologian knows ('scire') causes that should be investigated by ratio ('ratione investigari'), they are both 'equally successful in washing an

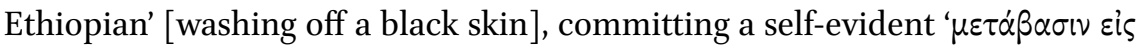
$\alpha 2 \lambda \circ \gamma^{\varepsilon} \varepsilon^{\prime} \varsigma^{\prime}$ ' ('transition to a different category'). ${ }^{63}$

61 See e.g. Bijlefeld, De islam als na-Christelijke religie, p. 20.

62 Reland, De fine mundi conditi, p. 26.

63 Reland, De libertate philosophandi, p. 8: 'Tum \& hoc caetera criterio a Theologia dignoscitur Philosophia, quod haec scientia, illa fide nitatur. Quae tantum inter se differunt, quantum a servitute philosophandi Libertas. Scientia rem per causas \& conclusiones inde deductas demonstrat. Fides testimonio confirmat. In Theologia Dei vox credere; in Philosophia recta ratio scire jubet. Illa Lumine gratiae, haec naturae nititur. Si quis ergo Philosophus credere velit dicentis testimonio hujus aut illius, i.e. se mancipare alicujus opinionibus, atque ita assensum praebere veritati authoritate tantum confirmatae, idem facit, ac si Theologus scire per causas, \& tremenda, quae fide revelat, mysteria (quae mysteria esse desinerent, si ratione investigari possent) obtusa ingenii caligantis acie studeat

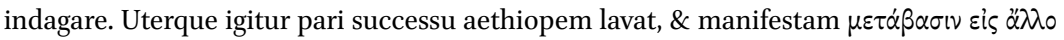
үévos instituit'. Reland took this expression from Aristotle. 
In his Harderwijk lecture, Reland again refers to Descartes in the following terms: 'We like the rule of Descartes, that whatever God has revealed, even if it goes beyond the powers of our mind, should be believed with unquestionable faith'.64 Reland found himself in the company of a number of Dutch Cartesians who defended the separation between philosophy (conceived as the mathematical philosophy of nature) on the one hand, and theology and its practical knowledge on the other. ${ }^{65}$ Precisely because Reland was educated in the intellectual atmosphere of ad fontes and critical methodology, and because he drew a rigorous separation between faith and science, he was able to follow the dual track of Christian-reformed believer (credere) on the one hand, and critical philosopher and especially philologist (scire) on the other. This enabled Reland to go beyond the paradigm of the dichotomy of religio falsa/religio vera and to have an eye for the study of different religions (and differences and similarities between religions) with their own creed, their own texts and their own rituals.

In this respect, let us examine the two disputations that dealt with the comparison of Judaism and Islam and the defence of the Christian creed of the Trinity. They are sometimes mentioned as early documents in which Reland used derogatory language about Jews, Muslims, and particularly Muhammad, whom he described as the 'pseudopropheta'. But his portrayal of Muhammad seemed ambivalent. Muhammad was an illiterate and downright uncivilized prophet but he was also endowed with an ingenious mind. ${ }^{66}$ Reland presented Islam as the 'reboiled cabbage of Judaism' 67 However, consider this extract from chapter VII of the Generalia of the Exercitatio philologico-theologica De consensu Mohammedanismi et Judaismi, in which he discusses the way in which one should investigate the Muslim faith:

Let us then consider here the Islam that is not wrapped in philosophical and theological shrewdness, as it is taught today in African Academies and elsewhere, but honest, pure and, as they say, in its natural state, as

\footnotetext{
64 Reland, De Incremento, quod Philosophia cepit hoc saeculo, p. 22: 'Nobis illa regula placet Cartesii, quodcunque Deus revelaverit, licet ingenii nostri vires excedat, indubia fide credi oportere'.

65 See Douglas, Spinoza \& Dutch Cartesianism. Chapter two in particular deals with the Dutch Cartesians and the Separation Thesis.

66 Reland, De consensu Mohammedanismi et Judaismi, p. 7: 'Ipse enim, licet callido praeditus ingenio, propheta tamen illiteratus \& plane rudis'.

67 Ibid., p. 5: 'Mohammedicam fidem, recoctam Judaismi cramben'.
} 
recorded by Muhammad in the Qurān and confirmed by the practice of its followers. [...] It is our duty to go to the pristine sources. ${ }^{68}$

After the Generalia, he discussed the points of community between the Mohammedans and Jews - both in creed and practice - in great detail, with extensive references to Jewish and Arabic sources, dealing in section I more specifically with the theory of religion, in section II with religious rites and customs, and in section III with stories and histories. ${ }^{69}$

In Reland, we see a young man caught up in the complexities of intellectual development. He came from a Protestant family, and was educated in the artes liberales at the Amsterdam Atheneum. He was then exposed to a Voetian reformed-pietistic theology at Utrecht (and Leiden); a humanist tradition of rhetoric, history and literature at Utrecht; ${ }^{70}$ a (neo-) Aristotelian world view that was gradually crumbling; Cartesian philosophy; the growth of experimental physics; a tradition of the study of Oriental languages, including Hebrew and Arabic; and the discovery of new worlds with religious systems never seen before.

Reland integrated these-sometimes abrasive-strands with his leitmotif: the desire for knowledge about, and critical study of, language, text and context. Instead of 'critical', I might have chosen 'modern', 'Cartesian', 'enlightened', or even 'radical'. However, 'critical' best conveys the notion that Reland was preoccupied with an independent critical examination of the world-its cultures, texts, languages and religions - around him. Moreover, the adjective 'critical' also restrains us from a single and exclusivist framing of his intellectual work. ${ }^{71}$

68 Ibid., p. 9: 'Caeterum spectabimus heic Mohammedanismum, non palliatum argutiis Philosophicis \& Theologicis, prout hodie in Africanis Academiis \& alibi docetur, sed integrum, purumque, \& in naturali, quod ajunt, statu, quemadmodum a Mohammede in Alcorano constitutus est \& praxis sequacium confirmatus. [...] Nostrum est integros accedere fontes'.

69 Ibid., p. 10: 'Sectio I. Speciatim in ARTICULIS RELIGIONIS, \& THEORIA Consensum ostendens'; p. 40: Sectio II In RITIBUS Religiosis \& PRAXI Consensum demonstrans'; p. 53: Sectio III In FABELLIS \& HISTORIIS' Mohammedanorum \& Judaeorum Consensum ostendens'.

70 An area for further research is the influence of the scholar, teacher and colleague Graevius on young Reland.

71 An interesting example of this — possibly unintentional-framing process is Reland's involvement with the Dutch translation of the Arabic story of the life of Hai ebn Jokdan. 
For Reland, academic work is first and foremost an ars critica. The Belgian scholar Michel Bastiaensen gives a balanced picture of the complexity of Reland's position in the following terms:

It seems that the role of Reland was that of an intermediary between scholarly orientalism and the philosophy of the Enlightenment; this is the meaning of the tribute that Voltaire bestowed upon him: '... until the time when "le sage Reland" gave us clear ideas of the Muslim belief'. And yet, we cannot say that Reland announces the Philosopher, this new model of humanity. Locked in his closet [...] somewhat isolated from the world, he seems to us rather like a Renaissance scholar ['un savant de la Renaissance']. ${ }^{72}$

We started this chapter by pointing to different intellectual currents that did not necessarily succeed each other in a linear fashion. Reland stood in a longer tradition of philological scholarship. His predecessors in the Netherlands included Scaliger, Golius, and Erpenius. In this respect he confirms the revisionist perspective developed by Dmitri Levitin when he rejects 'narratives of intellectual change from the linear and inconclusive emphasis on "enlightenment". ${ }^{33}$ However, at the same time, Reland himself experienced and articulated these personal experiences in his early writings, notably that he was living in a time of separation between the old and the new. In this, he almost literally—Reland lived from 1676 to 1718 -embodied the (to some outdated) perspective of Paul Hazard's classic La crise de la conscience européenne, who characterised the period $1680-1715$ as a sudden intellectual transition. ${ }^{74}$

Reland, a devout Protestant, was a savant, a critical ad fontes philologist, a Hebraist and Arabist, and a true representative of 'defenders of the text,' ${ }^{5}$ not a radical philosopher. What enabled Reland to go beyond the paradigm of a

This story acquired a pantheistic-Spinozist connotation. Some authors regard Reland's involvement in the Dutch translation in 1701 as an involvement in the new philosophy. However, as early as 1696 Reland quoted Abi Jaafar Ebn Tophail in Arabic in De symbolo Mohammedico, and referred to this as an 'Epistola sua elegantissima de Hai Ebn Jokdhan' (p. 9). In his De consensu, Reland again refers to this story (p. 27). There is no indication that in 1696 the young student Reland was aware of the Spinozist connotation this story would have later on.

72 Bastiaensen, 'Adrien Reland et la justification des études orientales', p. 26. Translation is mine.

73 Levitin, 'From sacred history to the history of religion', 2012, p. 1117. See also his Ancient Wisdom, 2015.

74 Hazard, The European Mind, p. 7.

75 Grafton, Defenders of the Text. 
Glaubenswissenschaft and to have an eye for different religious phenomena was a remarkable mix of intellectual curiosity, critical philology and critical methodology, grounded in the separation of theology and personal belief from science. He showed himself to be a scholar of religion who compared different religions, particularly the Abrahamic religions, in terms of creed, ritual, and text. Reland wanted to do justice to (the study of) religions and their adherents. Thus, he anticipated the 'emic' methodology of modern anthropologists and scholars of religion. ${ }^{76}$

\section{Bibliography}

\section{Sources}

Andreas, J., Confusio sectae Mahometanae. Interprete ex idiomate Italico Johanne Lauterbach, Utrecht, Johannes van Waesberge, 1656.

Burmann, C., Traiectum eruditum, virorum doctrina inlustrium qui in urbe trajecto, et regione trajectensi nati sunt, sive ibi habitarunt, vitas, fata et scripta, Utrecht, Jurrianus van Paddenburg, 1738.

Fèvre, T. Le, Les Vies des poètes grecs en abrégé, avec des remarques, Amsterdam, Thomas Myls, 1700.

Hooght, E. van der, Voor-reeden [preface], Lexicon Novi Testamenti Graeco-LatinoBelgicum, Amsterdam, Nicolaas Wassenaar, 1690.

Hottinger, J.H., Historia orientalis quae ex variis orientalium monumentis collecta, agit de Muhammedismo, de Saracenismo, de Chaldaismo, de statu Christianorum \& Judaeorum tempore orti \& nati Muhammedismi. Editio posterior, Tiguri [Zurich], Johann Jacob Bodmer, 166o.

Ibn Ṭufayl, Abū Bakr ibn Muhammad, Hayy b. Yaqzān, translated by J. Bouwmeester, De natuurlyke wysgeer, of Het leven van Hai ebn Jokdan, in het Arabisch beschreven door Abu Jaaphar Ebn Tophail. Voordezen uit de Latynsche overzetting van Eduard Pocok, A.M. in het Nederduitsch vertaald door S.D.B. En nu op nieuws met de Arabische grondtext vergeleken, en met aanmerkingen over eenige duistere plaatzen en spreekwyzen verrykt, Rotterdam, Pieter Van der Veer, 1701.

76 The emic approach is used to describe the religion of others in a way that believers in those religions will recognise themselves. According to Jan Platvoet, 'Students who practice this approach aim to do full justice to each particular religious world and to oppose their empathic, adherent-derived descriptions to the many biased representations of religions'. (Platvoet, Comparing Religions, p. 4.). By contrast, the etic approach focuses on the contextualization of religion as part of the development of a specific society or region, or the study of similarities of religions. 
Otth, J.H., Historia doctorum misnicorum qua opera etiam synedrii magni Hierosolymitani praesides et vice-praesides revensentur; additae sunt huic editioni notae ab harum literarum studioso [A. Reland], Amsterdam, Thomas Myls, 1699.

Reland, A., 'Saeculum argenteum, aeneum, ferreum'. in: Saeculum argenteum, aeneum, ferreum, ex Ovidio adumbratum, Amsterdam, Johann Rieuwerts, 1689, pp. A4r-v.

Reland, A., Q Horatii Flaccii, Epodon Od. 6. Quo, quo, scelesti, ruitis? \&c., Lib. 4. Od. 14. Quae cura patrum, quaeve Quiritium, \&c, in Paraphrases Horatianae seu Odae quaedam ex Horatio Elegiaco \& Heroico Carmine redditae. Per Bartholomaeum Bolk, Adrianum Reeland, Abrahamum Lakens, Christianum Cocq, Amsterdam, Johann Rieuwerts, 169 o.

Reland, A., Vindiciarum disquisitionis, De mente non ipsa cogitatione, Pars Prima, Utrecht, François Halma, 1694.

Reland, A., Exercitatio philosophica De fine mundi conditi, Utrecht, François Halma, 1694.

Reland, A., Exercitationis physico-mathematica De umbra Pars Prior, Utrecht, François Halma, 1694 .

Reland, A., Disputatio philosophica inauguralis, De libertate philosophandi, Utrecht, François Halma, 1694.

Reland, A., Ode in laudem poeseos Lucretianae, n.p., n.d. [1695].

Reland, A., Dissertationis historico-theologicae De sermone Dei in origine universi, Pars Tertia \& Ultima, Utrecht, François Halma, 1696.

Reland, A., Exercitatio philologico-theologica De consensu Mohammedanismi et Judaismi, Utrecht, François Halma, 1696.

Reland, A., Exercitatio philologico-theologica De symbolo Mohammedico (non est Deus nisi Unus) adversus quod S.S. Trinitas defenditur, Utrecht, François Halma, 1696.

Reland, A., Dissertatio historica De Philippi imperatoris patris et filii credito temere Christianismo, Leiden, Abraham Elzevier, 1698.

Reland, A., Disputatio theologica De paradisi sede temerè apud Jordanem quaesita, Leiden, Abraham Elzevier, 1698.

Reland, A., Oratio De Incremento, quod Philosophia cepit hoc saeculo, Amsterdam, Thomas Myls, 1700.

Reland, A., Oratio Pro lingua Persica et cognatis litteris Orientalibus, Utrecht, Willem vande Water, 1701.

Reland, A., Galatea, lusus poëticus, Amstelodami, sumtibus editoris, 1701.

Reland, A., De Religione Mohammedica libri duo. Quorum prior exhibet Compendium Theologiae Mohammedicae, ex Codice Manuscripto Arabice editum, Latine versum, \& Notis illustratum. Posterior examinat nonnulla, quae falso Mohammedanis tribuuntur, Utrecht, Willem Broedelet, 1705.

Reland, A., De religione Mohammedica Libri Duo. Editio altera auctior, Utrecht, Willem Broedelet, 1717 . 
Serrurier, J., Oratio funebris in obitum viri celeberrimi Hadriani Relandi, antiquitatum sacrarum et linguarum orientalium professoris ordinarii, recitata ipsis nonis Martiis MDCCXVIII, Utrecht, Willem vande Water, 1718.

Voetius, Disputatio de Muhammedismo, in Selectarum disputationum theologicarum, pars secunda, Utrecht, Johannes van Waesberge, 1655, pp. 66o-683.

\section{Studies}

Amerfoort, J. van, and W.J. van Asselt, Liever Turks dan Paaps? De visies van Johannes Coccejus, Gisbertus Voetius en Adrianus Relandus op de islam, Zoetermeer, Uitgeverij Boekencentrum, 1997.

Asselt, W.J. van, 'De islam in de beoordeling van Johannes Coccejus en Gisbertus Voetius', Kerk en theologie, vol. 46, 1995, pp. 229-251.

Bastiaensen, M., 'Adrien Reland et la justification des études orientales (1701)', Études sur le XVIII'e siècle, no. 1, (1974), pp. 13-27.

Bevilacqua, A., The Republic of Arabic Letters: Islam and the European Enlightenment, Cambridge, MA, The Belknap Press of Harvard University Press, 2018.

Bijlefeld, W.A., De islam als na-Christelijke religie; een onderzoek naar de theologische beoordeling van de islam, in het bijzonder in de twintigste eeuw [Islam as a postChristian religion; an inquiry into the theological evaluation of Islam, mainly in the twentieth century], Den Haag, Uitgeverij Van Keulen, 1959.

Certeau, M., The Writing of History, translated [original French edition L'Ecriture de l'histoire, published in 1975] by Tom Conley, New York, Columbia University Press, 1988.

Douglas, A., Spinoza \& Dutch Cartesianism; Philosophy and Theology. Oxford, Oxford University Press, 2015.

Dunkelgrün, Th., 'Like a Blind Man Judging Colors Joseph Athias and Johannes Leusden Defend their 1667 Hebrew Bible', Studia Rosenthaliana, vol. 44, 2012, pp. 79-115.

Gootjes, A., 'The Collegie der Sçavanten: A Seventeenth-Century Cartesian Scholarly Society in Utrecht', in Spaans, J. and J. Touber (eds), Enlightened Religion: From Confessional Churches to Polite Piety in the Dutch Republic, Leiden, Brill, 2019, pp. 156-182.

Goudriaan, A., Reformed Orthodoxy and Philosophy, 1625-1750: Gisbertus Voetius, Petrus van Mastricht, and Anthonius Driessen, Leiden and Boston, Brill, 2006.

Grafton, A., Defenders of the Text: The Traditions of Scholarship in an Age of Science, 1450-1800, Cambridge, MA, Harvard University Press, 1991.

Haan, A.A.M. de, Het wijsgerig onderwijs aan het Gymnasium Illustre en de Hogeschool te Harderwijk, 1599-1811, Harderwijk, Drukkerij Flevo, 1960.

Hamilton, A., 'Adriaan Reland: Outstanding Orientalist', in Commissie Geschiedschrijving van de Universiteit Utrecht (eds), Zes keer zestig: 360 jaar universitaire geschiedenis in zes biografië̈, Utrecht, Afdeling Grafische Zaken, 1996, pp. 23-31. 
Hamilton, A., 'From a "Closet at Utrecht": Adriaan Reland and Islam', Nederlands archief voor kerkgeschiedenis / Dutch Review of Church History, vol. 78, no. 2, 1998, pp. $243-5$ o.

Hamilton, A., 'The Study of Islam in Early Modern Europe', Archiv fürReligionsgeschichte, vol. 3, 2001, pp. 169-82.

Hamilton, A., 'Arabists and Cartesians at Utrecht', in P. Hoftijzer and T. Verbeek, Leven na Descartes; Zeven Opstellen over Ideeëngeschiedenis in Nederland in de tweede helft van de zeventiende Eeuw, Hilversum, Uitgeverij Verloren, 2005, pp. 97-105.

Hardy, N.J.S., The Ars Critica in Early Modern England, PhD Thesis, University of Oxford, 2012.

Hazard, P., The European Mind, 1680-1715, Hammondsworth, Penguin Books, 1964. First published as La Crise de la conscience européenne in 1935.

Helden, A.C. van, 'The Age of the Air-Pump', Tractrix: Yearbookfor the History of Science, Medicine, Technology and Mathematics, vol. 3, 1991, pp. 149-172.

Kernkamp, G.W., Acta et decreta Senatus: vroedschapsresolutiën en andere bescheiden betreffende de Utrechtsche academie, 3 vols., Utrecht, Broekhoff N.V.v/h Kemink en Zoon.

Krop, H., 'From Religion in the Singular to Religions in the Plural: 1700, a Faultline in the Conceptual History of Religion', in J. Spaans and J. Touber (eds), Enlightened Religion; From Confessional Churches to Polite Piety in the Dutch Republic, Leiden, The Netherlands, Brill, 2019, pp. 21-59.

Levitin, D., 'From Sacred History to the History of Religion: Paganism, Judaism, and Christianity in European Historiography from Reformation to "Enlightenment", The Historical Journal, vol. 55, no. 4, 2012, pp. 1117-116o.

Levitin, D., Ancient Wisdom in the Age of the New Science: Histories of Philosophy in England, c. 1640-1700, Cambridge, Cambridge University Press, 2015.

Nat, J.,De studie van de Oostersche talen in Nederland in de 18e en de 1ge eeuw, Purmerend, J. Muusses, 1929.

Platvoet, J., Comparing Religions, a Limitative Approach: An Analysis of Akan, Para-Creole, and Ifo-Sananda Rites and Prayers (Religion and reason, 24), The Hague, Mouton, 1982.

Rooden, P.T. van, 'The Amsterdam Translation of the Mishnah', in W. Horbury (ed.), Hebrew Study from Ezra to Ben-Yehuda, Edinburgh, T\&T Clark, 1999, pp. 257-267.

Ruestow, E.G., Physics at Seventeenth and Eighteenth-Century Leiden: Philosophy and the New Science in the University, International Archives of the History of Ideas, Series Minor 11, The Hague, Martinus Nijhoff, 1973.

Ruler, J.A. van, The Crisis of Causality: Voetius and Descartes on God, Nature, and Change, Leiden and New York, E.J. Brill, 1995.

Shapin, S. and Schaffer, S., Leviathan and the Air-Pump: Hobbes, Boyle, and the Experimental Life, Princeton, NJ, Princeton University Press, 1985. 
Spaans, J. and J. Touber, 'Introduction Enlightened Religion: From Confessional Churches to Polite Piety in the Dutch Republic', in Spaans, J., and J. Touber, J. (eds), Enlightened Religion; From Confessional Churches to Polite Piety in the Dutch Republic, Leiden, Brill, 2019, pp. 1-18.

Stroumsa, G.G., A New Science:The Discovery of Religion in the Age of Reason, Cambridge, MA, Harvard University Press, 2010.

Stroumsa, G.G., 'From Abraham's Religion to the Abrahamic Religions', Historia Religionum, vol. 3, 2011, pp. 11-22.

Stroumsa, G.G., 'The History of Religions as a Subversive Discipline: Comparing Judaism, Christianity and Islam', in V. Krech et al. (eds), Dynamics in the History of Religion between Asia and Europe: Encounters, Notions, and Comparative Perspectives, Leiden, Brill, 2012, pp. 149-158.

Thijssen-Schoute, C.L., Nederlands cartesianisme'; avec sommaire et table de matières en français. Bezorgd en van aanvullende bibliografie voorzien door Th. Verbeek, Utrecht, HES, 1989.

Touber, J., Spinoza and Biblical Philology in the Dutch Republic, 1660-1710, Oxford, Oxford University Press, 2018.

Turner, J.C., Philology: The Forgotten Origins of the Modern Humanities, Princeton, NJ, Princeton University Press, 2014.

Verbeek, Th., 'Descartes and the Problem of Atheism: The Utrecht Crisis', Nederlands Archief voor Kerkgeschiedenis / Dutch Review of Church History, vol. 71, no. 2, 1991, pp. 211-223.

Verbeek, Th., Descartes and the Dutch: Early Reactions to Cartesian Philosophy, 16371650, Carbondale [etc.], Southern Illinois University Press, 1992.

Vrolijk, A. and R. van Leeuwen, Arabic Studies in the Netherlands: A Short History in Portraits, 1580-1950, translated by A. Hamilton, Leiden and Boston, Brill, 2014. 